\title{
The role of aerobic and anaerobic bacteria in non gonococcal urethritis (NGU) in men
}

\author{
Haitham M. Al-Habib*, Haitham B. Fathi** \\ * Department of Microbiology, ** Department of Medicine, College of Medicine, University of Mosul.
}

(Ann. Coll. Med. Mosul 2010; 36 (1 \& 2): 99-105).

Received: $17^{\text {th }}$ Oct 2010; Accepted: $9^{\text {th }}$ Feb 2011.

\begin{abstract}
Objectives: To identify causative microorganisms of nongonococcal (NGU) urethritis in men.

Methods: A descriptive comparative study included 240 male patients with urethritis and 40 agematched males free from urethritis was carried out. The urethral swabs were inoculated on different culture media and incubated both aerobically and anaerobically.

Results: A 153 patients were considered as NGU cases. From them, 18 genera of aerobic and anaerobic microorganisms were isolated. Aerobic bacterial isolates were two times the anaerobic bacterial isolates. The type of growth was heavy among patients in comparison to scanty growth among controls. The most common microorganism in each group were Staph. epidermidis, Gardnerella vaginalis, and Bacteroides species.

Conclusion: Aerobic and anaerobic microorganisms are associated with urethritis in men. The confluent growth and dramatic response after treatment by appropriate antibiotics confirm the roles of the isolated bacteria in development of NGU in men.
\end{abstract}

Key words: Urethritis, nongonococcal urethritis, aerobic \& anaerobic bacteria.

الخلاصة

$$
\text { الأهداف: تشخيص أنواع الجر اثيم المسببة لخمج الاحليل غير السيلاني وغير الكلاميدي عند الرجال. }
$$

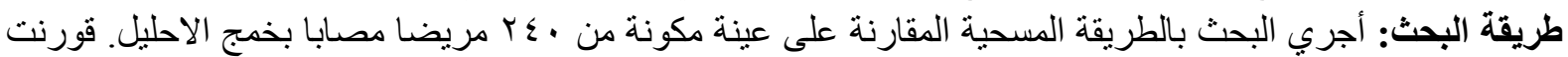

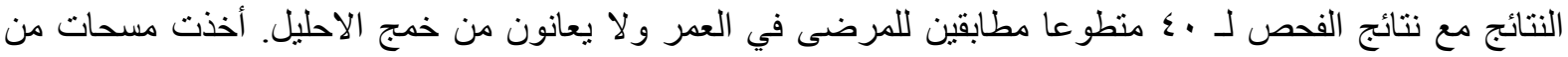

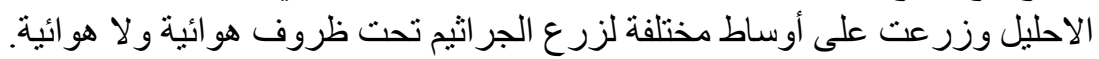

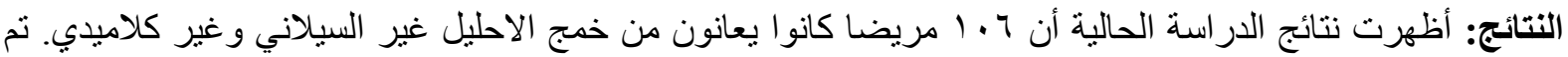

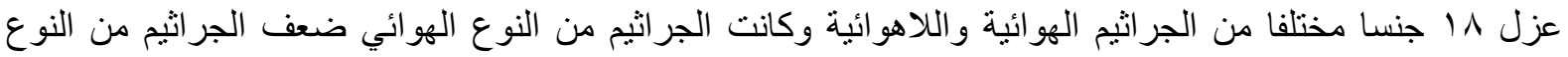

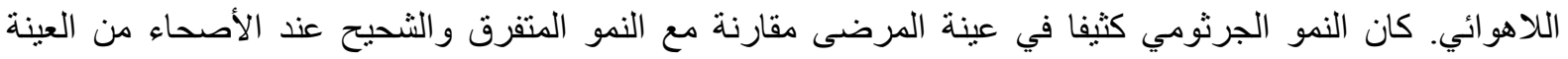
الضابطة. أن أكثر أنواع الجر اثثم شيو عا في كل مجموعة هي المكور ات العنقودية الجلدية، الكاردنيريلا المهبلية وجر اثثيم الباكتيرويدس.

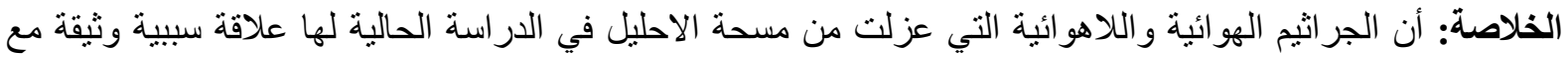

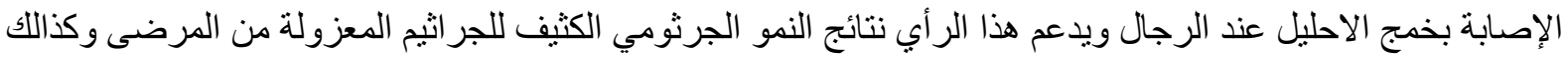

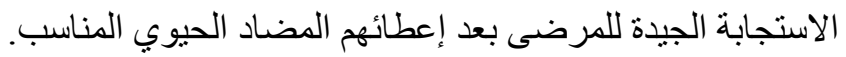

rethritis is a common sexually transmitted disease in men ${ }^{(1)}$. Around half of the cases are caused by Chlamydia trachomatis and Neisseria gonorrhea and the second half are caused by other microbes ${ }^{(2,3,4)}$. The latter is called nonchlamydial nongonococcal urethritis (NCNGU). The NGU is a common condition frequently diagnosed in 
sexually transmitted diseases clinics all over the world ${ }^{(3)}$. It is the most common condition diagnosed and treated in men who attend departments of genitourinary medicine in the United Kingdom ${ }^{(5)}$. Despite the extensive studies, its prevalence among urethritc group and the etiology remain controversial ${ }^{(6)}$. In addition to the causative bacterial pathogens associated with NGU, it has been demonstrated that there was a significant relationship of Mycoplasma genitalium with acute $\mathrm{NGU}^{(7)}$. The major effort applied to identify novel pathogens have employed culture methods mainly ${ }^{(8,9)}$. However, molecular techniques have believed that documented cultured microorganisms to date represent fraction of the total pathogens ${ }^{(10)}$. Because information regarding NGU is lacking in our locality, this study was conducted aiming the determination of the causative bacteria of NGU.

\section{Patients and methods}

This study was approved by the Scientific Research Committee at the College of Medicine, University of Mosul. Formal consent was taken from all patients and control subjects after careful explanation.

The present study includes 240 males presented with signs and symptoms of urethritis who attended the Dermatology and Venereology Clinics at Mosul Teaching Hospital or referred from private clinics to the Department of Microbiology, College of Medicine, University of Mosul, during the period from April, 2007 to March 2009. The age of the patients ranged from 18 to 52 years with mean and standard deviation of $(26.3 \pm 7.9)$ years, while that of the control subjects varied from 22 to 45 years with mean and standard deviation of $(24.5 \pm 5.8)$ years. The patients who used antibiotics during the last two weeks, those with visible urethral deformities such as hypospadias, stricture, surgical interference or others, and patients who refused to participate in the study were excluded. A total of 240 patients were enrolled in the current study. The patients were suffering from penile irritation, urethral discharges and/ or dysuria. The urethral meatus of each patient was washed with a sterile gauze soaked in sterile distilled water, then a $30 \mathrm{ml}$ of first voided urine was collected into sterile tubes. The urethritis was confirmed microscopically on the basis of $>6$ polymorphonuclear leukocytes (PMNs) per $\mathrm{ml}$ in sediments of urine samples ${ }^{(1)}$. In addition urethral swabs were obtained for diagnostic purposes.

The patients were treated with the appropriate antibiotics namely ciprofloxacin $500 \mathrm{mg}$ twice daily for one week and / or doxycycline $500 \mathrm{mg}$ twice daily for one week.

A control subjects of 40 male volunteers with no signs and symptoms of urethritis who matched the patients by age ( 22 to 45 years) were asked to participate in this study. The inclusion criteria included married, absence of urethral discharge after urethral squeezing and have $<6 \mathrm{PMNs} / \mathrm{ml}$ in urine sediment.

\section{Microbiological methods}

The urethral swabs were inoculated directly onto chocolate agar plates and blood agar base plates containing $5 \%$ sheep blood that had been held in anaerobic jar with Gas Pak generating kit (Oxoid, U.K.). Other blood agar plates were also inoculated and incubated aerobically in $5 \% \mathrm{CO}_{2}$ atmosphere. In addition, different culture media were used namely sodium thioglycolate broth, cooked meat medium, MacConkey's agar, Sabouroud's dextrose agar, and modified Thayer Martin agar. Also mycoplasma specific medium (Oxoid, U.K.) was used for isolation of mycoplasma species. All the inoculated culture media were held at temperature between $35^{\circ} \mathrm{C}$ to $37^{\circ} \mathrm{C}$ for 24 hours with further 48 hours incubation if there is no growth. Identification of the isolates was relied upon their colonial morphology, gram reaction, and standard biochemical tests ${ }^{(9)}$.

\section{Statistical analysis}

The data has been processed and analyzed by the use of statistical package SPSS version 11. A bivariate data were analyzed by $x^{2}$ test, $\mathrm{df}=1$. A value of $<0.5$ was considered statistically significant. 


\section{Results}

Among the examined 240 urethral discharge specimens, 87 (36.2\%) were positive for Neisseria gonorrhea by both gram stain and culture. The remaining $153(63.8 \%)$ were considered as non gonococcal urethritis (NGU). Among them 106 (69.3\%) yielded a positive bacterial growth, while the remaining 47 patients $(30.7 \%)$ showed a negative growth. Different 18 genera of aerobic and anaerobic microorganisms were detected from the patients and controls (Tables 1, 2, and 3). Some cases yielded a single microorganism, while other cases showed a mixed bacterial growth. The ratio of aerobic to anaerobic microorganisms was $2: 1$ and the ratio of aerobic gram positive to gram negative microorganism was 1.6: 1. The most common isolates of aerobic gram positive bacteria were Staph. epidermidis $(26.4 \%)$, Corynebacterium species $(17.0 \%)$ and lactobabacilli (15.1\%). G. vaginalis (13.2\%) and Escherichea coli (9.4\%) represent the most frequent gram negative isolates. Bacteroides species (15.0\%), Peptostreptococcus (13.2\%), and Prevotella melaninogenicus $(11.3 \%)$ were the dominant anaerobic isolates. Also, 11 isolates of Mycoplasma and 6 isolates of Candida albicans were detected. The difference in Staph. epidermidis and total aerobic Gram's positive bacterial isolates between patients and controls was statistically significant, while the rest of differences were statistically nonsignificant. Overall the type of growth of the isolated microorganisms were heavy growth $(+++)$ among patients in comparison to scanty growth isolates among control subjects. This means that the number of isolated colonies obtained from studied patients was greater than that resulted from control group. Among the tested 40 control subjects, only 34 of them showed a positive culture growth while negative growth was obtained from the remaining 6 individuals.

Table (1): Percentage of aerobic gram positive bacteria isolated from patients with NGU and control group.

\begin{tabular}{|c|c|c|c|c|c|c|c|c|}
\hline \multirow{2}{*}{ Microorganism } & \multicolumn{3}{|c|}{$\begin{array}{c}\text { NGU } \\
N=106\end{array}$} & \multicolumn{3}{|c|}{$\begin{array}{c}\text { Control } \\
\mathrm{N}=40\end{array}$} & \multirow{2}{*}{$\begin{array}{l}\text { NGU } \\
\text { vs. } \\
\text { control }\end{array}$} & \multirow{2}{*}{ P-value ** } \\
\hline & No. & $\%$ & $\begin{array}{l}\text { Type of } \\
\text { growth* }^{*}\end{array}$ & No. & $\%$ & $\begin{array}{l}\text { Type of } \\
\text { growth }\end{array}$ & & \\
\hline Staph. epidermidis & 28 & 26.4 & +++ & 4 & 10.0 & + & $2.6: 1$ & 0.02 \\
\hline Corynebacterium & 18 & 17.0 & +++ & 6 & 15.0 & + & 1.1:1 & 0.49 \\
\hline Lactobacilli & 16 & 15.1 & +++ & 8 & 20.0 & + & $1: 1.3$ & 0.31 \\
\hline a-h.streptococci & 12 & 11.3 & ++ & 3 & 7.5 & + & $1.5: 1$ & 0.36 \\
\hline Ent.faecalis & 8 & 7.5 & + & 2 & 5.0 & + & $1.5: 1$ & 0.45 \\
\hline Staph.saprophyticus & 2 & 1.9 & + & 2 & 5.0 & + & $1: 2.6$ & 0.30 \\
\hline Total & 84 & 79.2 & & 25 & 62.5 & & $1.2: 1$ & 0.03 \\
\hline
\end{tabular}

* $(+)$ scanty, $(++)$ moderate, $(+++)$ heavy growth ${ }^{* *} x^{2}$ test, $d f=1$

Table (2): Percentage of aerobic gram negative bacteria isolate from with NGU and control group.

\begin{tabular}{|c|c|c|c|c|c|c|c|c|}
\hline \multirow{2}{*}{ Microorganism } & \multicolumn{3}{|c|}{$\begin{array}{c}\text { NGU } \\
N=106\end{array}$} & \multicolumn{3}{|c|}{$\begin{array}{c}\text { Control } \\
\mathrm{N}=40\end{array}$} & \multirow{2}{*}{$\begin{array}{c}\text { NGU } \\
\text { vs. } \\
\text { control }\end{array}$} & \multirow{2}{*}{ P-value } \\
\hline & No. & $\%$ & $\begin{array}{l}\text { Type of } \\
\text { growth }\end{array}$ & No. & $\%$ & $\begin{array}{l}\text { Type of } \\
\text { growth }\end{array}$ & & \\
\hline G. vaginalis & 14 & 13.2 & ++ & 4 & 10.0 & + & $1.3: 1$ & 0.41 \\
\hline Esch. coli & 10 & 9.4 & +++ & 4 & 10.0 & + & $1: 1.1$ & 0.56 \\
\hline Acinetobacter & 8 & 7.5 & +++ & 2 & 5.0 & + & $1.5: 1$ & 0.45 \\
\hline Klebsiella & 7 & 6.6 & ++ & 4 & 10.0 & + & $1: 1.5$ & 0.35 \\
\hline P. aeruginosa & 4 & 3.8 & +++ & 2 & 5.0 & + & $1: 1.3$ & 0.52 \\
\hline Proteus sp. & 4 & 3.8 & +++ & 4 & 10.0 & + & $1: 2.6$ & 0.14 \\
\hline H. parainflunzae & 3 & 2.8 & + & 0 & 00.0 & - & - & - \\
\hline H. influnzae & 1 & 0.9 & + & 0 & 00.0 & - & - & - \\
\hline Total & 51 & 48.1 & & 20 & 50.0 & & $1: 1$ & 0.49 \\
\hline
\end{tabular}


Table (3): Percentage of anaerobic gram positive and gram negative bacteria isolate from patients with NGU and control group.

\begin{tabular}{|l|c|c|c|c|c|c|c|c|}
\hline \multirow{2}{*}{ Microorganism } & \multicolumn{3}{|c|}{ NGU } & \multicolumn{3}{c|}{$\begin{array}{c}\text { Control } \\
\text { N=40 }\end{array}$} & \multirow{2}{*}{$\begin{array}{c}\text { NGU vs. } \\
\text { control }\end{array}$} & \multirow{2}{*}{ P-value } \\
\cline { 2 - 9 } & No. & $\%$ & $\begin{array}{c}\text { Type of } \\
\text { growth }\end{array}$ & No. & $\%$ & $\begin{array}{c}\text { Type of } \\
\text { growth }\end{array}$ & & \\
\hline Peptostreptococcus & 14 & 13.2 & +++ & 3 & 7.5 & + & $1.8: 1$ & 0.25 \\
\hline P. melaninogenius & 12 & 11.3 & +++ & 2 & 5.0 & + & $2.2: 1$ & 0.20 \\
\hline Prop. acne & 10 & 9.4 & ++ & 6 & 15.0 & + & $1: 1.6$ & 0.24 \\
\hline Lactobacilli & 10 & 9.4 & ++ & 8 & 20.0 & + & $1: 2.1$ & 0.07 \\
\hline B. corodons & 8 & 7.5 & ++ & 1 & 2.5 & + & $3: 1$ & 0.23 \\
\hline B. fragilis & 8 & 7.5 & ++ & 2 & 5.0 & + & $1.5: 1$ & 0.45 \\
\hline Eubacterium & 6 & 5.6 & ++ & 1 & 2.5 & + & $2.2: 1$ & 0.38 \\
\hline Total & 68 & 64.1 & & 23 & 57.5 & & $1.1: 1$ & 0.29 \\
\hline
\end{tabular}

\section{Discussion}

Regarding the etiology of NGU in males, it is appropriate to distinguish between acute and chronic disease. This study included only acute cases of urethritis. The etiology of NGU is multifactorial ${ }^{(10,11)}$. Both aerobic and anaerobic bacteria were isolated from almost all sexually active non-urethritis (NU) men and males with $\mathrm{NGU}^{(12)}$. This corresponds well with this study where different genera of aerobic and anaerobic bacteria were obtained. In the current study, except for staph. epidermidis, no significant differences were noted among different aerobic and anaerobic isolates between patients and control subjects. This is in agreement with results of other groups who had examined the urethral flora of males with and/or without urethritis ${ }^{(13-15)}$ and mentioned that no differences between NGU patients and NU men. Moreover, Bowie et al. ${ }^{(12)}$ reported that aerobic lactobacilli, G. vaginalis, alphahaemolytic streptococci, and Bacteroides were isolated significantly more frequently from the NU group than NGU patients. However some investigators had low isolate rate for aerobes $^{(13)}$. In another study at least one aerobe was isolated from $93 \%$ or more of individuals ${ }^{(12)}$. Mehta etal isolated few Staph. epidermidis, but many Staph. aureus ${ }^{(14)}$. Also, Helmholz in USA ${ }^{(16)}$ reported isolation of Staph. aureus which has not been obtained in more recent studies including the present study. Staph. epidermidis and other coagulase negative staphylococci are normal commensals of the skin, but increasing importance of these microorganisms as human pathogens has been recognized over the past 25 years $^{(17)}$. Many studies confirmed rising frequency of infections caused by these microorganisms ${ }^{(18)}$. In the current work Staph. epidermidis constituted the dominant aerobic gram positive isolate $(26.4 \%)$ followed by Corynebacterium species $(17.0 \%)$ which was in agreement with other studies ${ }^{(12)}$ who reported that Staph. epidermidis was isolated from $96 \%$ of patients with Chlamydia trachomatis positive NGU and in $88 \%$ of individuals with $\mathrm{C}$. trachomatis negative NGU. These high isolation percentages of Staph. epidermidis and that recorded in the current study are attributed to the great ability of this microorganism to attach firmly on biot or abiot surfaces which is facilitated by its natural hydrophobic nature. In addition Staph. epidermidis produces a viscous extracellular polysaccharide slim as biofilm which provides additional adhesion to the epithelial surfaces of urethra and resistance to multiple antimicrobial agents ${ }^{(19)}$. Davis etal reported a relatively high recovery of corynebacterium species, but there was a nonsignificant difference between men with or without $\mathrm{NGU}^{(15)}$. Also, the rate of isolation of so-called NGU corynbacteria by Furness et al was the same for normal as for patients with $\mathrm{NGU}^{(20)}$. G. vaginalis constituted $13.2 \%$ out of the total isolates of gram negative bacteria which was quite different from the finding in other studies who recovered $\mathrm{G}$. vaginalis in percentage of $4.6 \%$ and $6.9 \%$ respectively ${ }^{(12,21)}$. However, other investigators proposed that $\mathrm{G}$. vaginalis was the cause of some cases of $\mathrm{NGU}^{(22)}$. 
Riemersma et al reported that Pseudomanslike bacterial species were identified relatively frequently. Really many of the gram negative bacilli recovered by Ambrose and Taylor ${ }^{(23)}$ were Pseudomonas aeruginosa which was also detected in the current study in percentage of $3.8 \%$. The detection of diversity of Pseudomonas-like bacterial species suggests that there is much to explore in the bacterial flora of the male urethra. Whereas the detection of bacterial species that disappear upon disease development may have important implication to the therapy of NGU. The prevalence of NGU and the pathogenic potential of these bacterial species need to be defined more precisely. This requires the development of diagnostic tests for these elusive microorganisms that allow larger group of patients to be screened. In addition, various species of the genus Haemophilus have been implicated in $\mathrm{NGU}^{(24)}$. In the present study $\mathrm{H}$. parainflunzae $(2.8 \%)$ and $\mathrm{H}$. influenzae $(0.9 \%)$ were isolated from NGU patients but were not encountered among healthy controls. This is unsuitability with results of other investigators ${ }^{(1)}$. Acinetobacter $(7.5 \%)$ appeared as a distinct causative agent of NGU in our results, which was also confirmed by other workers ${ }^{(12)}$.

In the current study different genera of anaerobes were detected from both NGU patients and controls (Table 3 ). This result goes with that of other workers who suggested that anaerobes could be recovered from both patients with NGU and healthy people, hence they are part of normal urethral flora ${ }^{(12)}$. However other investigators have either failed to isolate anaerobes from patients with NGU and/or men without urethritis ${ }^{(13,25)}$. In addition, other investigators recovered them in small fraction. In contrast to other studies, Hafiz et al reported a great correlation between NGU and urethral infection with Clostridium difficile ${ }^{(26)}$. In this study no single isolate of $C$. difficile was seen in both gram stain and anaerobic culture. The Bacteroides species were recovered from $(15.0 \%)$ of the total cases which is really somewhat higher than the results of other workers who reported percentages of $12.5 \%$ and $3.9 \%$ respectively ${ }^{(27,18)}$. However other investigators didn't isolate Bacteroides species from any case of $\mathrm{NGU}^{(28)}$. The high isolation rates of Peptostreptococcus (13.2\%) and Prevotella $(11.3 \%)$ among anaerobes were in agreement with the finding of other investigators $^{(12)}$.

Mycoplasma genitalium is one of the pathogens of male urethritis and is usually transmissible ${ }^{(29)}$. Recent data by Bjornellius et al revealed that $M$. gentitalium could be detected in more than $36 \%$ of patients ${ }^{(11)}$. The study done by Totten, et al showed a strong association of $\mathrm{M}$. genitalium and NGU in $22 \%$ of patients and $4 \%$ of control group ${ }^{(5)}$. In 1996, Jensen, et al reported that four M. genitalium strians were isolated from urethral swab of men with $\mathrm{NGU}^{(30)}$. In the current study Mycoplasma species constituted $10.4 \%$ out of the total 106 growth positive cases and in $3.8 \%$ of the control group. This somewhat low isolation rate of Mycoplasma may be due to the need of further sophisticated identification procedures which are not available in our department at the meantime. The increasing evidence of the association of $M$. genitalium with urethritis in men implies the need for further studies assessing the potential treatment and prevention strategies. Moreover, clinical diagnostic molecular test such as PCR could be helpful for detection of M. genitalium in both men and women.

The recorded 47 negative cases may be attributed to other causes such as Chlamydia trachomatis, Herpes simplex viruses, adenoviruses, or Trichomonas vaginalis.

In conclusion, most of the isolated bacteria in the current study represent part of the normal flora of urethra of patients and control group. But, the heavy growth of different pathogens obtained from patients in contrast to the scanty type noted in control subjects may indicate the capability of these bacteria to adhere firmly to epithelial surfaces of urethra which lead to infection. Another important evidence confirms the involvement of these bacteria in urethritis was the good response obtained in patients after treatment with the appropriate antibiotics where there was no urethral discharge and symptoms of dysuria and itching subsided. 


\section{References}

1. Riemersma WA, van der Schee CJC, van der Meijden WI, et al. Microbial Population Diversity in the Urethras of Healthy Males and Males Suffering from Nonchlamydial, Nongonococcal Urethritis. J. Clin. Microbiol. 2003; 1977-1986.

2. Janier M, Lassau F, Casin I, et al. Male urethritis with or without discharge: a clinical and microbiological study. Sex Transm. Dis. 1995; (22): 244-252.

3. Burstein GR, Zenilman J M. Nongonococcal urethritis: a new paradigm. Clin. Infect. Dis. 1999; (28): S66-S73.

4. Horner P, Thomas B, Gilroy BC, et al. Role of Mycoplasma genitalium and Ureaplasma urealyticum in acute and chronic nongonococcal urethritis. Clin. Infect. Dis. 2001; (32): 995-1003.

5. Hughes G, Simms I, Rogers PA, et al. New cases seen at genitourinary medicine clinics: England 1997. Commun Dis Rep CDR Suppl 1998; 8(Suppl): S1-11.

6. Totten PA, Schwartz MA, Sjostrom KE, et al. Association of Mycoplasma genitalium with Nongonococcal Urethritis in Heterosexual Men. JID. 2001; (183): 269276.

7. Horner PJ, Gilroy CB, Thomas BJ, et al. Association of Mycoplasma genitalium with acute non-gonococcal urethritis. Lancet 1993; 342:582-5.

8. Stefanik M, Rychna K, Valkoun A. Microbial causative agents of male urethritis. J. Hyg. Epidemiol. Microbiol. Immunol. 1992; (36): 111-118.

9. Gall $H$, Beckert $H$, Meier-Ewert $H$, et al. Pathogen spectrum of urethritis in the man. Hautartzt. 1999; (50): 186-193.

10. Schmidt TM, Relman D. Phylogenetic identification of uncultured pathogens using ribosomal RNA sequences. Methods Enzymol. 1994; (235): 205-222.

11. Murray PR, Baron EJ, Pfaller MA, et al. Manual of clinical of Microbiology $7^{\text {th }}$ ed. American society for Microbiology. 1999. Washington, D.C.

12. Association of Genitourinary Medicine and the Medical Society for the Study of Venereal Diseases. National guidelines for the management of non-gonococcal urethritis. Sex Transm. Infect. 1999; (75): S9-S12.

13. Bjornelius $E$, Lidbrink $P$, Jensen $J S$. Mycoplasma genitalium in non-gonococcal urethritis: a study in Swedish male STD patients. Int. J. STD AIDS. 2000; (11): 292-296.

14. Bowie WR, Pollock HM, Forsyth PS, et al. Bacteriology of the Urethra in Normal Men and Men with Nongonococcal Urethritis. J. Clin. Microbiol. 1977; 482-488.

15. Morrison A I. Investigation of nongonococcal urethritis by anaerobic culture. Br. J. Vener. Dis. 1963; (39): 118-120.

16. Mehta U S, Rana VS, Vaishnav VP. A bacteriological study of acute urethritis. Indian J. Pathol. Bacteriol. 1967; (10): 170-176.

17. Davis G, Smithurst B, Talbot A, et al. Microbiological studies on non-gonococcal urethritis in Brisbane. Med. J. Aust. 1973; (2): 268-271.

18. Helmholz HF. Determination of the bacterial content of the urethra: a new method, with results of a study of 82 men. J. Urol. 1950; 64: 158-166.

19. Gillespie SH, Hawkey PM. Principles and practice of clinical bacteriology. $2^{\text {nd }}$ edition. John Wiley and sons, Ltd. 2006, p.103.

20. Sehaberg DR, Culver DH, Gaynes RP. Major trends in the microbial etiology of nosocomial infection. The American Journal of Medicine. 1991; 91(S3B) 72-75.

21. Ryan KJ, Ray CG. Sherris Medical Microbiology, An introduction to infectious diseases. $4^{\text {th }}$ edition. McGraw-Hill Publishing Division. 2004, p. 270.

22. Furness G, Kamat KL H, Kaminski Z, et al. An investigation of the relationship of nonspecific urethritis corynebacteria to the other microorganisms found in the urogenital tract by means of a modified chocolate agar medium. Invest. Urol. 1973; (10) :378-391.

23. Al-Yazachi M, Dabbagh R, Al-Obeidi S. Nongonococcal Urethritis In Males. Journal of Community Medicine. 1988; 1 (2): 89-92. 
24. Dunkelberg WE, Woolvin S C. Haemophilus vaginalis relative to gonorrhea and male urethritis. Mil. Med. 1963; (128): 1098-1101.

25. Ambrose LSS, Taylor WW. A study of the etiology, epidemiology, and therapeusis of nongonococcal urethritis. Am. J. Syph. Gonorrhea and Vener. Dis. 1953; (37): 501-513.

26. Sturm AW. Haemophilus influenzae and Haemophilus parainfluenzae in nongonococcal urethritis. J. Infect. Dis. 1986; (153): 165-167.

27. Justesen $T$, Nielson $M$ L, Hattel $T$. Anaerobic infections in chronic prostatitis and chronic urethritis. Med. Microbiol. Immunol. 1973; (158): 237-248.

28. Hafiz S, McEntegart M G, Morton R S, et al. Clostridium difficile in the urogenital tract of males and females. Lancet. 1975: 420-421.
29. Swartz SL, Kraus SJ, Herrmann KL, et al. Diagnosis and etiology of nongonococcal urethritis. The journal of infectious diseases. 1978; 138 (4): 445-454.

30. Hallen A, Ryden AC, Schwan A, et al. The possible role of anaerobic bacteria in the etiology of nongonococcal urethritis in men. British Journal of Venereal Disease. 1977; (53): 368-371.

31. Hamasuna R, Osada $Y$, Jensen JS. Isolation of Mycoplasma genitalium from First-Void Urine Specimens by Coculture with Vero Cells. J. Clin. Microbiol. 2007: 847-850.

32. Jensen JS, Hansen H T, Lind K. Isolation of Mycoplasma genitalium strains from the male urethra. J. Clin. Microbiol. 1996; (34): 286-291. 